\title{
The economics of cell phone reuse and recycling
}

\author{
Roland Geyer • Vered Doctori Blass
}

Received: 1 December 2008 / Accepted: 20 July 2009/Published online: 4 September 2009

(C) The Author(s) 2009. This article is published with open access at Springerlink.com

\begin{abstract}
There is widespread consensus that landfill of waste electronic and electric equipment is not an acceptable end-of-use management option. Diversion from landfill, either through voluntary or mandatory take-back and collection programs, overwhelmingly leads to the recycling of e-waste, which typically consists of the recovery of a limited number of metals. Cell phones are currently one of the few electronic products, if not the only one, that also have a thriving reuse market. In fact, more handsets are reused than recycled. Cell phones therefore offer the rare opportunity to compare closed-loop supply chains for e-waste reuse and recycling. In this paper, we examine the economics of cell phone reuse and recycling based on detailed primary data collected from reverse logistics, reuse and recycling operations in 2003 in the UK and in 2006 in the US. We show that while cell phone reuse has a healthy profit margin, handset recycling is currently a by-product of reuse.
\end{abstract}

Keywords WEEE - Cell phones · Reuse - Recycling ·

Production economics $\cdot$ Closed-loop supply chains

\section{Introduction and literature review}

The pace at which technology and sales of cell phones have been developing since their market launch 25 years ago has been extraordinary. When Motorola's DynaTAC received approval by the US Federal Communications Commission in 1983, it weighed $800 \mathrm{~g}$, was $33 \mathrm{~cm} \mathrm{high,} \mathrm{and} \mathrm{cost}$ $\$ 4,000$. Merely 20 years later, 1.2 billion handsets had been sold worldwide. Global sales in 2003 alone were over 470

R. Geyer $(\bowtie) \cdot$ V. Doctori Blass

Donald Bren School of Environmental Science and Management, University of California,

Santa Barbara, CA 93106, USA

e-mail: geyer@bren.ucsb.edu

V. Doctori Blass

e-mail: vdoctori@bren.ucsb.edu million handsets [1]. In 2008, over 280 million handsets were sold in just the first quarter, which suggests that global sales doubled within those 5 years [2]. This outstanding market success, together with the short average lifetime of cell phones, made them a target of environmental activism, policy, and research, even though cell phones are just one example of the ever increasing array of electronic products. The corresponding rising tide of waste electrical and electronic equipment (WEEE) is increasingly subject to environmental scrutiny and policy based on extended producer responsibility, such as the European WEEE Directive or California's Assembly Bill AB 2901 [3, 4]. Diversion from landfill based on such legislation typically leads to e-waste recycling. Unlike most other electronic products, however, cell phone recycling and reuse are equally established, while more end-of-use handsets are actually being reused than recycled. This creates the rare opportunity to compare closed-loop supply chains of e-waste recycling and reuse.

The overall objective of this paper is therefore to investigate and quantify the economic performance of the reverse logistics, reuse, and recycling operations for end-ofuse cell phones. In-depth economics analysis of cell phone reuse and recycling helps us understand the business models and drivers as well as the operational strategies and challenges that underlie and surround these closed-loop supply chains. The research focuses in particular on thirdparty take-back enterprises, which emerge as the central agents of most reverse logistics, reuse, and recycling operations for handsets. The assessments are based on detailed primary data collected from reverse logistics, reuse, and recycling operations in 2003 in the UK and in 2006 in the USA $[5,6]$. The paper complements another recent submission which contains a detailed assessment of the environmental performance of the same reverse logistics, reuse, and recycling operations (Geyer R, Doctori Blass V. The role of displaced production for reuse and recycling: the example of cell phone end-of-life management. J Ind Ecol, under review). 
Research literature on cell phones in particular, rather than electronic products and e-waste in general, emerged around 10 years ago, when they were singled out and targeted by European policy makers [7]. The subsequent industry-initiated research (the so-called Cellular Phones Take-back Working Group of the European Trade Organization for the Telecommunication and Professional Electronics Industry (ECTEL) trials) led to a series of publications, which contained energy and cost assessments of the cell phone life cycle, in particular, their end-of-use management [8-10]. Cell phone manufacturers continued these efforts with similar basic assessments of material composition and energy requirements [11-14]. At the same time, the literature on product remanufacturing in management science and industrial engineering discovered cell phones as a case study but was mostly focused on production and operations management issues [15-19]. Guide et al. [20] and Skerlos et al. [21] added economic and/or environmental assessments to their industrial engineering research on cell phone remanufacturing. Similar research on cell phone and computer recycling was published by Bhuie et al. [22] whose largely qualitative environmental assessment focuses on diversion from landfill.

In 2004, cell phone manufacturers published more comprehensive life cycle assessments of cell phones [23, 24]. Other environmental assessment methods, like environmental footprint analysis and material input per unit service, were also explored but with mixed results [25, 26]. Huisman [27] applied his own environmental assessment methodology of e-waste recycling to cell phones, while Scharnhorst et al. [28] conducted life cycle assessments of an entire cell phone network with different recycling scenarios. Several leaching assessments of cell phones are also available in literature [29-31]. Uryu et al. [32] provide an assessment of gallium and arsenic releases due to cell phone incineration. In 2005 and 2006, Nokia published the final reports of its Integrated Product Policy Pilot Project with fairly comprehensive overviews of life cycle environmental assessments and improvement options [1, 33, 34]. At the same time, the Mobile Phone Partnership Initiative between the United Nations Environment Program's Basel Convention and most cell phone manufacturers published a series of guidelines on environmentally sound cell phone end-of-use management [35].

This paper is organized as follows. Section 2 explains in some detail how cell phones are retired, collected, and recycled or reused. Sections 3.1 to 3.3 present and analyze the economics of the main end-of-use management processes, which are reverse logistics, recycling, and reuse. Section 3.4 discusses the resulting business model of cell phone take-back enterprises, while Section 3.5 explains the issue of displaced production. Section 4 contains conclusions and suggests future research.

\section{Cell phone end-of-use management}

Despite its overall similarity with the disposal of other WEEE, cell phone end-of-use management stands out on at least two accounts. First, the amount of retired handsets has grown even more rapidly than other WEEE. The global number of cell phone subscribers has grown exponentially in the last 15 years: 16 million in 1991, 60 million in 1995, 470 million in 1999, 1.33 billion in 2003, and 2.5 billion in 2007 [33, 35, 36]. The number of end-of-use handsets increased even faster than this since cell phone lifetimes have been decreasing, from 3 years in 1991 to 18 months by 2002 and probably even less today. According to [37], $60 \%$ of all 2007 sales in emerging markets were already replacement sales. Second, cell phones have a thriving second hand market, and more handsets are currently reused than recycled. Some environmental agencies are thus interested in understanding the drivers behind this in order to apply it to other WEEE [38].

\subsection{Cell phone retirement and collection}

How, when, and why electronic products are being retired and disposed of has only recently received the attention of researchers [39-41]. Early examples of such research were the ECTEL trials of a consortium of cell phone manufacturers, which included two user surveys in 1997 and 2001 $[8,42]$. The main reason for retiring handsets emerged to be their replacement with new models, while the rate of replacement had increased substantially between the two surveys. It is estimated that current replacement times are between 1 and 2 years, while manufacturers believe that the technical lifetime is in the order of 10 years [33]. For this reason, retired handsets tend to be in good working condition. Important reasons for the frequent replacement are the heavy discounts offered by airtime providers as well as the constant product innovation by handset manufacturers. Surveys also consistently show that owners of electronic products typically keep them beyond the end of the use phase for a variety of reasons, such as perceived residual value and lack of knowledge regarding proper WEEE disposal $[1,39,43]$. The ECTEL trial survey results suggest that, in principle, handset owners are open to the concept of returning end-of-use handsets, given that return programs are available and convenient. However, there is currently very little data available on actual cell phone disposal. Due to their small size and weight, cell phones are easy to discard and difficult to detect in municipal solid waste. It is assumed, however, that most of the estimated 130 million handsets that were retired in 2005 in the USA had not been landfilled by 2006 [44].

There is significantly more data available on end-of-use cell phone collection. According to those numbers, only a 
fraction of the cell phones being retired is collected. The US Environmental Protection Agency, for example, estimates that the current collection rate in the USA is below $20 \%$ [45]. End-of-use cell phones are collected by a variety of agents. Municipalities and counties collect WEEE since they are typically in charge of waste management, yet their share of collected handsets is minimal [6]. Original Equipment Manufacturer (OEMs) and network service providers take back end-of-use handsets as a customer service, as part of their corporate environmental responsibility program or for compliance reasons. They usually outsource these operations to third-party enterprises. These take-back enterprises such as Greener Solutions and Shields in the UK and ReCellular, PaceButler, RMS, and CollectiveGood in the USA have identified the collection of end-of-use cell phones as a business opportunity and, apart from alliances with OEMs and network providers, team up with non-profit organizations and retailers to access the stock of retired handsets. They are by far the most proactive cell phone collectors and handle, directly or indirectly, the vast majority of collected phones. Collection methods range from drop-off bins to prepaid envelopes or boxes. There are essentially two end-of-use fates for collected handsets, regardless of the reverse logistics channel: reuse or recycling [35].

\subsection{Cell phone recycling}

Like all electronic products, cell phones consist of a multitude of different components, which in turn are made of many different materials and substances. By cell phone recycling, we mean the process of material recovery from obsolete handsets without batteries and accessories. The collection or recycling agents remove the batteries, which have their own recycling paths, and all collected accessories, which are likely to end up in landfill as non-hazardous waste [1]. In order to assess the recycling potential of cell phones, it is necessary to know their material composition, which therefore has been subject to a range of studies. A summary of their findings is available in (Geyer R, Doctori Blass V. The role of displaced production for reuse and recycling: the example of cell phone end-of-life management. J Ind Ecol, under review). The reported material compositions of handsets for model years 1996 to 2003 are in relatively good agreement, given the wide range of product models and the fast pace of product innovation. Comparison with older product models, however, show that handset mass and material composition had changed considerably during the 1980s and early 1990s, which is unsurprising given the immaturity of cell phones at that stage. More recent models consist of roughly $25 \%$ metals, $30-50 \%$ plastics with the remainder being glass, ceramics, and epoxy $[8,12,13,27]$. The majority of the metal mass is made up of copper, steel, and aluminum.
Most material composition analyses of cell phones focus on their metal content. This is for two reasons: First, the majority of environmental concerns regarding landfill of handsets come for their content of heavy metals, such as lead, nickel, chromium, and copper. However, there are some other substances of concern as well, an example being toxic flame retardants such as polybrominated biphenyls and polybrominated diphenyl ether. Second, cell phone recycling currently only recovers metals, in particular, copper, silver, gold, and the platinum group metals. More comprehensive recycling processes, such as those described in [46] and [47] would also recover ferrous metals, aluminum, magnesium, lead, nickel, zinc, and tin, i.e., virtually $100 \%$ of the metal content of cell phones [27, 46, 47]. However, current cell phone recycling operations are limited to copper and precious metals, i.e., they recover between $48 \%$ and $64 \%$ of the metals fraction, or $12 \%$ to $19 \%$ of the total cell phone [35, 48-50]. Almost all of this recycled material is copper.

Even recycling all of the metals would not be enough to meet the relevant recycling target of the European WEEE directive, which is $65 \%$ for IT and telecommunications equipment (category 3 products) plus an additional 10\% energy recovery [3]. To meet this target, it would be necessary to also recycle the plastics and ceramics fraction of the cell phone. In the current recycling practice, the entire cell phone is being crushed without any prior disassembly. The crushed handset is then smelted together with other copper-rich feedstock. Meeting the $65 \%$ of mass recycling target would require additional disassembly and separation steps and most likely even redesign of the handset [51]. This is unlikely to happen, however, since requirements of the WEEE directive apply to equipment categories as a whole and not to individual product types like cell phones. Since cell phones make up only a small fraction of category 3 WEEE, it will be much more costeffective to focus product and process redesign efforts on other (bulkier) category 3 products like computers.

\subsection{Cell phone reuse}

In contrast to other electronic products, end-of-use cell phones have a thriving reuse market. Our data suggest that in the USA, $65 \%$ of all collected cell phones are reused rather than recycled [6]. Data from UK take-back enterprises indicate reuse yields, i.e., percentages of collected end-of-use phones being reused, as being well over $50 \%$ [5]. Unfortunately, there is currently no consistent terminology for product reuse. The various terms that are being used usually reflect the level of reprocessing that is involved. Refurbishment typically indicates a modest and remanufacturing a substantial level of reprocessing. Reuse is the generic term for product recovery, but often also points towards no or little reprocessing. Cell phone reuse 
and refurbishment is not done by OEMs but by the thirdparty take-back enterprises mentioned earlier. After the cell phones have been collected and shipped to their premises, the refurbishers inspect and sort the handsets into those that can be reused and those that have to be recycled. Whether handsets can be reused depends on their functional and cosmetic condition and the existence of a secondary market for the handset make and model. Frequently, refurbishers use software programs and databases to increase the efficiency and effectiveness of the sorting operations. The reprocessing operation can range from simple testing to genuine repair or reconditioning of parts or subassemblies. Extent and type of reprocessing is chosen in order to maximize financial return. All handsets that cannot be reused are sent to recyclers. Reuse and recycling of cell phones are therefore not independent of each other. In fact, since refurbishers handle the vast majority of collected end-of-use handsets, they are also the largest source of cell phones for recycling [6]. Recyclers, on the other hand, are currently not engaged in end-of-use cell phone collection.

Most of the reused phones are sold to developing or emerging economies. UK refurbishers export almost all of their cell phones to Africa, the Far East, the Middle East, and Eastern Europe. In the USA, reused handsets are exported to Latin America, Africa, Asia, and Eastern Europe or resold within the country $[5,6]$. The mobile communication standard used by a country is a significant remarketing constraint. Global System for Mobile communication (GSM) dominates Europe and is widespread in Africa and Asia, whereas Time Division Multiple Access (TDMA) and Code Division Multiple Access (CDMA) prevail in the Americas. Nevertheless, all interviewed industry experts say that demand for secondary handsets outstrips supply for all major standards. Currently, cell phone reuse is purely market-driven, since no country has legislation that mandates reuse. The WEEE directive states that "where appropriate, priority should be given to the reuse of WEEE and its components, subassemblies, and consumables", but has no mandatory reuse targets analogous to its collection, recovery, and recycling targets [3]. One of the main reasons for the viability of cell phone reuse is the short average handset life. However, as mentioned earlier, most retired cell phones are simply stored by their owners rather then returned through the available reverse logistics channels. This appears to be the main obstacle for increased collection and reuse of handsets. The biggest challenge for refurbishers is thus to decrease this hibernation period of retired handsets.

\section{Economics of cell phone reuse and recycling}

Some reuse and recycling activities are voluntary and environmentally motivated, yet most are driven either by market economics or legislation. Apart from the previously mentioned European WEEE directive and California's AB2901, there is currently little legislation mandating cell phone reuse or recycling. Even the WEEE directive has fairly modest collection targets (4 kg of WEEE per head per year) of any type of e-waste, whereas AB2901 only mandates a collection infrastructure for cell phones and has neither collection nor reuse or recycling targets. So, in the absence of strong legislation, profitability is currently the main driver of the collection and reprocessing of retired handsets. Assessing the economics of cell phone reuse and recycling is thus critical in order to understand current types and levels of end-of-use management activities. The main economic costs of cell phone end-of-use management are reverse logistics and reprocessing, which is either recycling or some level of refurbishment. The two main sources of revenues are the sale of refurbished handsets for reuse and the sale of the recovered metals on the commodity markets. The existence of both cell phone reuse and recycling show that there are viable business models around both activities. In the following three sections, we identify those business models, quantify their profitability, and discuss the relationship between reuse and recycling.

\subsection{Reverse logistics}

Reverse logistics costs can be divided into three parts: return incentive, collection and shipping, and inspection and sorting. The purpose of the return incentive is to motivate the owners of retired handsets to return them through the reverse logistics channel of the collecting agent. In the case of reuse, it is important to collect retired handsets as soon as possible, since the value of secondary
Table 1 Average reverse logistics costs for several cell phone take-back enterprises

\begin{tabular}{lll}
\hline Process & $\begin{array}{l}\text { Average cost US 2006 } \\
(2006 \text { dollar/phone })\end{array}$ & $\begin{array}{l}\text { Average Cost UK 2003 } \\
\text { (2006 dollar/phone) }\end{array}$ \\
\hline Return incentive & 3 & 6.2 \\
Collection and shipping & 1.9 & 2.6 \\
Inspection and sorting & 2.8 & 2.2 \\
Total & 7.7 & 11.0 \\
\hline
\end{tabular}


Table 2 Average cell phone recycling costs and revenues for two ewaste recyclers

\begin{tabular}{lll}
\hline & $\begin{array}{l}\text { US 2006 } \\
\text { (2006 dollar/phone) }\end{array}$ & $\begin{array}{l}\text { UK 2003 } \\
\text { (2006 dollar/phone) }\end{array}$ \\
\hline Average Cost & 0.18 & 0.36 \\
Average Revenue & 0.75 & 0.90 \\
\hline
\end{tabular}

phones decreases rapidly with time. Return incentives vary widely across collecting agents and geographies. Some agents will offer to buy back the phone, while others will only cover shipping costs. The buy-back price can range from a few dollars to $\$ 40-50$, depending on handset model and condition [6]. Some agents use donations to charities as return incentive, which has been found to work well in some countries and not at all in others [5]. Table 1 shows the average costs of the three reverse logistics processes for several take-back enterprises in the UK in 2003 and in 2006 in the USA [5, 6]. The 2003 pound have first been converted into 2003 dollar using the average annual exchange rate from the Federal Reserve Bank of New York and then converted in 2006 dollar using the gross domestic product deflator of the US Bureau of Economic Analysis.

The cost data in Table 1 shows a fair degree of consistency across time and geography. The individual reverse logistics costs obviously very much depend on the business model and operations of the collecting agent. Agents that focus on high-end phones are willing to pay a high price to capture those phones as soon as possible (see, e.g., www.RIPmobile.com), while those with less selective collection strategies will aim to keep reverse logistics costs low. OEMs that are engaged in cell phone take-back and reprocessing usually do this through third parties. In some cases, the third party pays the OEM a certain amount per collected phone of their brand; in others, the OEM pays the third party for its service. Independent of how reverse logistics of retired cell phones are organized, its economic costs are currently substantial. This is in agreement with literature that states that reverse logistics costs make up $80 \%$ of total end-of-use management cost for WEEE [52].

\subsection{Recycling}

The data in Table 2 show average revenue and cost (in 2006 dollar) per handset as they are reported from one e-waste recycler in the UK in 2003 (Else Refining) and one in the US in 2006 (ECS Refining) [5, 6]. Both show small profit margins of roughly $\$ 0.5$, which means that efficiency and economies of scale are critical to ensure profitability. However, cell phones are not an important source of income for e-waste recyclers, since they process many types of electronic waste, with cell phones being only a small portion of their business. These recyclers also only consolidate and pre-process electronic waste and then send it to primary metal smelters and refineries, like Boliden or Xstrata, for the actual metal recovery.

Secondary material sales are the ultimate source of cell phone recycling revenues. These revenues can therefore be estimated by multiplying the amounts of recovered metals reported from three different cell phone recyclers with their market value $[8,49,53,54]$. Table 3 shows that the results are in very good agreement with the revenue data obtained from the two e-waste recyclers. Table 3 also shows that around $70 \%$ of the recycling revenues are from the gold contained in handsets, whereas from a mass point of view, cell phone recycling is essentially copper recycling. Again, the overall results are remarkably constant across time and geography. This is partially due to two countervailing trends: Whereas the precious metal content of phones has a downward trend over time, the prices of $\mathrm{Cu}, \mathrm{Ag}, \mathrm{Au}$, and Pd have been increasing between 2003 and 2006 [54]. The decreasing amount of recoverable precious metals per handset is a compound effect of two trends, the reduction in handset mass over time and the reduction in precious metals content over time.

Figure 1 shows average handset mass and gold content from 1992 to 2004. The data series have been synthesized from a variety of sources $[8,27,49,53,55]$. It shows a reduction in hand set mass of $66 \%$ and in gold content of $60 \%$ over this period of time. Handset mass has leveled off at around $80 \mathrm{~g}$, which is due to consumer preference rather than technical feasibility. Gold content might yet further decrease. As a result of both trends, the amount of
Table 3 Potential revenues from cell phone recycling based on high and low values from actual metal recovery rates from three cell phone recyclers

\begin{tabular}{|c|c|c|c|c|c|c|}
\hline \multicolumn{3}{|c|}{ Recycled material (g/phone) } & \multicolumn{2}{|c|}{ Metal price (dollar/g) } & \multicolumn{2}{|c|}{ Recovered value (dollar/phone) } \\
\hline Element & Low & High & 2003 & 2006 & Low and 2006 & High and 2003 \\
\hline Copper $(\mathrm{Cu})$ & 8.84 & 14.85 & 0.0018 & 0.0068 & 0.06 & 0.03 \\
\hline Silver (Ag) & 0.30 & 0.31 & 0.16 & 0.36 & 0.11 & 0.05 \\
\hline Gold (Au) & 0.028 & 0.037 & 12.87 & 21.52 & 0.61 & 0.47 \\
\hline Palladium (Pd) & 0.012 & 0.019 & 6.53 & 10.61 & 0.13 & 0.13 \\
\hline Total & 9.2 & 15.2 & & & 0.90 & 0.68 \\
\hline
\end{tabular}




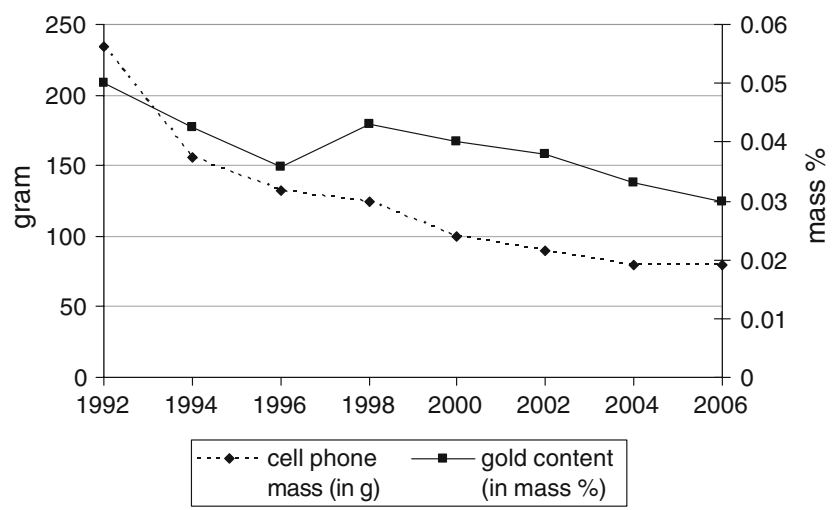

Fig. 1 Change in average handset mass and gold content between 1992 and 2006

recoverable gold per handset has decreased from around 0.12 to $0.025 \mathrm{~g}$ (Fig. 2). The value of recoverable gold per handset followed this trend until 2000. Since then, the rising gold price has kept the value of recoverable gold per handset stable and even slightly increased it in 2006 (Fig. 2). Nevertheless, it is evident from Fig. 2 that the economics of recycling has been deteriorating over time and is unlikely to recover significantly. Table 4 shows that the revenues from handset recycling could not be improved by recovering more metals. In the table, the high and low values of metal composition data from four different sources are multiplied with the respective metal prices in 2006 [8, 12, 13, 28, 54]. In both cases, the currently recovered metals (shown in italics) make up over $95 \%$ of the total value.

In summary, the economics of cell phone recycling has been declining since its beginning in the early nineties and currently offers a small profit margin. However, cell phone recycling is only profitable if recyclers do not have to bear any reverse logistics costs. The combined cost of cell phone collection and recycling would far outweigh its revenues. Cell phone recycling is economically self-sustaining only if the reverse logistics costs are absorbed by agents other than the e-waste recyclers.

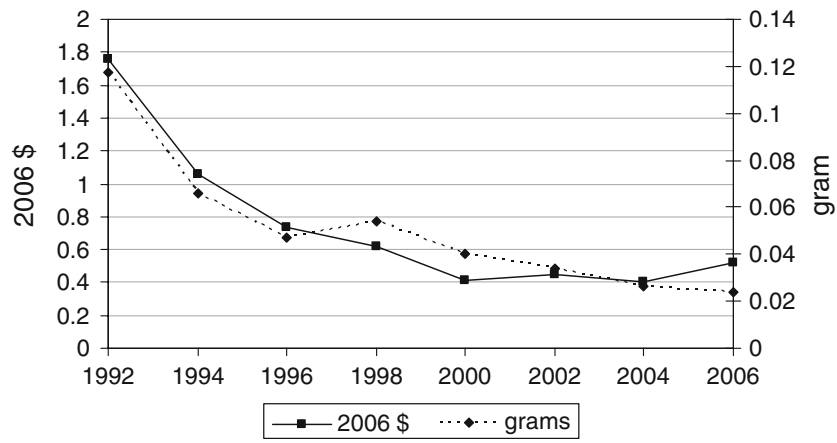

Fig. 2 Declining mass and value of recoverable gold per handset between 1992 and 2006
Table 4 Value of recoverable metals in cell phones, based on material composition data from four different sources $[8,12,13,27]$

\begin{tabular}{|c|c|c|c|c|c|}
\hline & \multicolumn{2}{|c|}{ Mass (in g) } & \multirow{2}{*}{$\begin{array}{l}\text { Metal price } \\
\text { in } 2006 \\
\text { (cents/g) }\end{array}$} & \multicolumn{2}{|c|}{$\begin{array}{l}\text { Value of recoverable } \\
\text { metals (in cents) }\end{array}$} \\
\hline & High & Low & & High & Low \\
\hline Silver (Ag) & 0.90 & 0.11 & 36.01 & 32.41 & 4.03 \\
\hline Aluminum (Al) & 7.20 & 1.52 & 0.27 & 1.94 & 0.41 \\
\hline Gold (Au) & 0.033 & 0.026 & $2,151.71$ & 70.15 & 56.12 \\
\hline Chromium (Cr) & 0.72 & 0.20 & 0.82 & 0.59 & 0.16 \\
\hline Copper $(\mathrm{Cu})$ & 20.68 & 9.30 & 0.68 & 14.09 & 6.33 \\
\hline Iron $(\mathrm{Fe})$ & 6.62 & 2.70 & 0.10 & 0.66 & 0.27 \\
\hline Nickel (Ni) & 2.74 & 0.70 & 2.43 & 6.64 & 1.70 \\
\hline Lead $(\mathrm{Pb})$ & 0.80 & 0.28 & 0.17 & 0.14 & 0.05 \\
\hline Palladium (Pd) & 0.09 & 0.00 & $1,060.97$ & 93.37 & 0.00 \\
\hline Tin $(\mathrm{Sn})$ & 0.80 & 0.43 & 0.92 & 0.74 & 0.39 \\
\hline Zinc (Zn) & 0.92 & 0.27 & 0.35 & 0.32 & 0.10 \\
\hline Total & 41.57 & 15.56 & & 221.03 & 69.56 \\
\hline
\end{tabular}

\subsection{Reuse}

Table 5 shows average refurbishment cost and resale value per handset in 2003 in the UK and in 2006 in the USA (both in 2006 USD). The values are derived from fairly comprehensive datasets which cover the major cell phone refurbishers in the UK in 2003 (Shields, Greener Solutions) and in the USA in 2006 (ReCellular, PaceButler, RMS). In both cases, cell phone reuse is profitable, even if all reverse logistics costs are included. The resale value of individual handsets varies widely and depends on brand and model, as well as grade, age, and condition. Table 6 shows the average resale prices of different handset grades of a US refurbisher in 2006 and their fraction of his total stock. The grades are based on the condition of the handset and the amount of reprocessing. For example, many handsets are only tested and cosmetically cleaned without further disassembly or parts replacement. In contrast to traditional forward supply chains, where inputs from suppliers are typically designed and produced to meet the specifications and demand from their customers, the inputs to closed-loop supply chains are the end-of-use products retired from the product users and thus directly dependent on new product sales and user behavior.

Table 5 Average costs and revenues from cell phone refurbishment and resale

US 2006 (dollar/phone) UK 2003 (dollar/phone)

$\begin{array}{lcc}\text { Average cost } & 2.1 & 1.76 \\ \text { Average revenue } & 17 & 23\end{array}$


Table 6 Estimated average handset resale prices of a US refurbisher in 2006

\begin{tabular}{lll}
\hline Grade & $\begin{array}{l}\text { Average resale price } \\
\text { (in dollar) }\end{array}$ & $\begin{array}{l}\text { Average percent of } \\
\text { total stock }\end{array}$ \\
\hline Repair stock & 10 & 27 \\
$\begin{array}{l}\text { Beyond economic } \\
\text { repair (BER) }\end{array}$ & 17 & 25 \\
Untested & 20 & 18 \\
Tested & 30 & 27 \\
Refurbished & 48 & 3 \\
Total & 20.1 & 100 \\
\hline
\end{tabular}

Table 7 shows new handset sales in 2006 with the lowend price range making up $60 \%$ of the market volume but generating only $35 \%$ of the total revenues [6]. It is these newly sold handsets that will be the potentially available inputs for cell phone refurbishers once they are retired. The importance of product model and model year is reconfirmed by the data in Table 8, which show the resale values of a selection of Nokia handsets for two different resale dates [55]. The wide range in resale values reflects the wide range in new product prices. Equally important as the original product model, however, is the timing of the resale. It can be seen that within 8 months, the handset models lost between $20 \%$ and $30 \%$ of their resale value.

That this is a persistent and pervasive property of the cell phone resale market is shown in Figs. 3 and 4, which show the resale values of a range of handsets over a similar period of time in 2002/2003 in the UK and 2005/2006 in the USA $[6,55]$. It appears that the higher the initial resale value, the more pronounced is its decline. In some cases, the price increases before it further decreases. These fluctuations are due to short-term changes in market demand, availability of quantities, etc. It directly follows from Figs. 3 and 4 that one major challenge of cell phone refurbishers is to minimize the time period between retirement and return of end-of-use cell phones. Significant time sensitivity of resale values has also been observed with commercial product returns [56, 57].

Table 7 Market composition of new product sales in 2006 in the USA

\begin{tabular}{|c|c|c|c|c|}
\hline \multirow[t]{2}{*}{ Category } & \multicolumn{2}{|c|}{ US market share } & \multirow{2}{*}{$\begin{array}{l}\text { Price range } \\
\text { (in dollar/ } \\
\text { phone) }\end{array}$} & \multirow{2}{*}{$\begin{array}{l}\text { Average price } \\
\text { (in dollar/ } \\
\text { phone) }\end{array}$} \\
\hline & $\begin{array}{l}\text { Revenue } \\
(\%)\end{array}$ & $\begin{array}{l}\text { Volume } \\
(\%)\end{array}$ & & \\
\hline High-end & 20 & 7 & $226-500$ & 356 \\
\hline $\begin{array}{l}\text { Mid- } \\
\text { range }\end{array}$ & 45 & 33 & $131-225$ & 166 \\
\hline Low-end & 35 & 60 & $1-130$ & 72.5 \\
\hline
\end{tabular}

Table 8 Resale values of different Nokia models

\begin{tabular}{llll}
\hline Product model & Model year & $\begin{array}{l}\text { Resale value } \\
\text { September 2002 } \\
\text { (in pound) }\end{array}$ & $\begin{array}{l}\text { Resale value } \\
\text { April 2003 } \\
\text { (in pound) }\end{array}$ \\
\hline Nokia 6210 & 2000 & 65 & 49 \\
Nokia 3310 & 2000 & 40 & 32 \\
Nokia 3210 & 1999 & 28.50 & 20 \\
Nokia 3110 & 1997 & 10.50 & 8.50 \\
\hline
\end{tabular}

The refurbishment costs shown in Table 5 are very small and suggest that very little reprocessing takes place. Surveys of cell phone reuse practices in Europe and the USA indeed show that reprocessing is typically kept to a minimum, since the cost of most reprocessing operations is higher than the resulting increase in resale value $[5,6]$. We estimate that over $90 \%$ of all resold cell phones collected in the USA receive no or minimal reprocessing, such as testing, basic cosmetic treatment, and software updates. Interviews with managers from European take-back enterprises yielded similar results.

\subsection{Business models for cell phone reuse and recycling}

We are now going to discuss profitability and business models of refurbishers, which are the central agents of the closed-loop supply chain for cell phones, since they handle the vast majority of collected end-of-use handsets. Figure 5 shows the estimated average operating profits of refurbishers in 2006 in the USA and in 2003 in the UK as a function of the reuse yield. In both cases, average operating profits are calculated as

$$
\begin{aligned}
\Pi= & r\left(R_{\text {reuse }}-C_{\text {reuse }}\right)+(1-r) \times\left(R_{\text {recycle }}-C_{\text {recycle }}\right) \\
& -C_{\text {revlog }},
\end{aligned}
$$

with the costs and revenues from Tables 1,2, and 5, and $r$ being the reuse yield, i.e., the fraction of collected cell phones that can be reused. Coincidentally, both profit functions break even at $50 \%$ reuse yield, the only difference being that the profit function of 2003 UK refurbishers has a higher gradient, i.e., grows faster with increasing reuse yield, than the profit function of 2006 US refurbishers. The reason for this is that in the 2003 UK case $R_{\text {reuse }}-C_{\text {reuse }}$ is around $\$ 6.30$ larger than in the 2006 US case, which is mostly due to the $\$ 6$ difference in average revenue. However, this is partially offset by a downward shift of the 2003 UK profit function relative to the 2006 US one. The reason for this is that the 2003 UK reverse logistics cost are \$3.30 higher than those of the 2006 US case, which is almost exclusively due to a higher average return incentive. 
Fig. 3 Resale values of 12 handset models from September 2002 to April 2003 in the UK

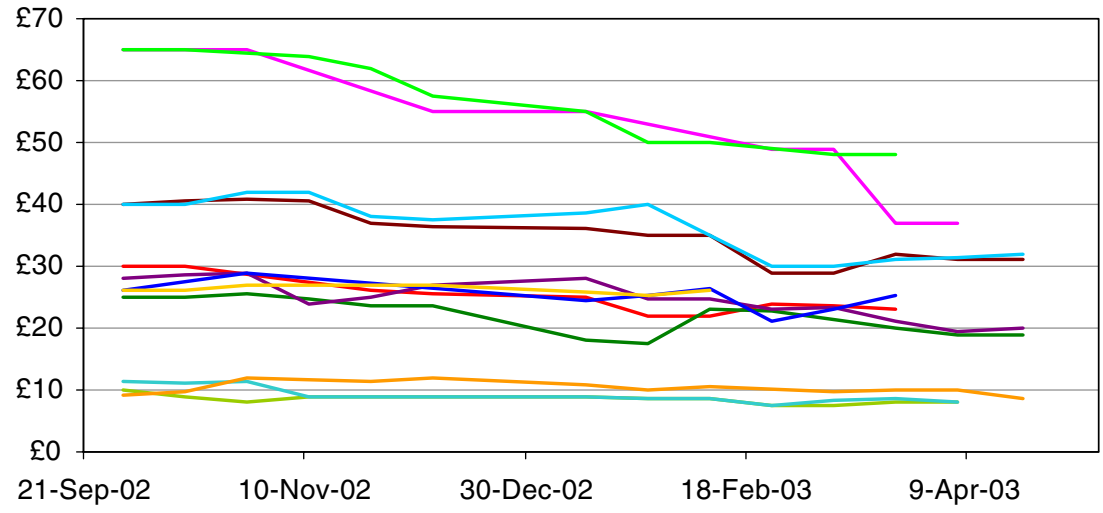

Since all refurbishers report reuse yields higher than $50 \%$, they can afford to bear the cell phone collection cost and offer the return incentives required to successfully access the pool of stored end-of-use handsets. In fact, cell phone recycling is currently mostly a side-effect of cell phone reuse, since most of the recycled handsets are rejects from refurbishers. Business models and costs are very similar regarding cell phone recycling, which primarily serves to reduce losses from non-reusable handsets and increase the environmental reputation of the refurbishers. European refurbishers also offer to ensure WEEE compliance for industrial suppliers of retired cell phones. Handset reuse processes and costs are also very similar across refurbishers, none of which engage in major reprocessing operations as mentioned earlier. The main challenge of refurbishers is thus to choose return incentives and collection systems that maximize the difference between resale values and reverse logistics costs. The most significant differences between business models are thus approaches to and methods of handset collection.

There are at least three different strategies for handset collection: One is to minimize collection cost, which typically means that no return incentive is paid, and bulk collection and shipping methods are used, e.g., through the use of collection bins. The second strategy usually involves a fixed return incentive, regardless of handset make and model, and individual shipping, such as prepaid shipping envelopes. The third strategy uses a buy-back rather than a take-back approach with the size of the return incentive depending on handset make and model. We do currently not have enough data to compare the efficiency and effectiveness of these different reverse logistic strategies.

\subsection{The issue of displaced production}

Reused cell phones are functional substitutes for new handsets, and there exists a vigorous debate about the extent to which cell phone reuse reduces new cell phone sales, also called cannibalization. Cannibalization takes place when a customer, who would have otherwise purchased a new cell phone, decides to buy a reused one instead. The reduced production volume that results from the reduced sales volume of new handsets is called displaced production. The third party refurbishers described in this paper are indeed regarded as a cannibalization threat by some original cell phone manufacturers. The economics of cell phone refurbishers are not affected by cannibalization, since they have no financial stake in new cell phone production. Nevertheless, a high cannibalization rate, or even merely the perception that it might be high, could have significant indirect impacts for refurbishers. High actual or perceived cannibalization generates strong economic disincentives for manufacturers to support the reverse logistics channels of refurbishers or create cell phone designs that facilitate reuse. Indeed, some manufacturers only support
Fig. 4 Resale values of five handset models from January 2005 to February 2006 in the USA

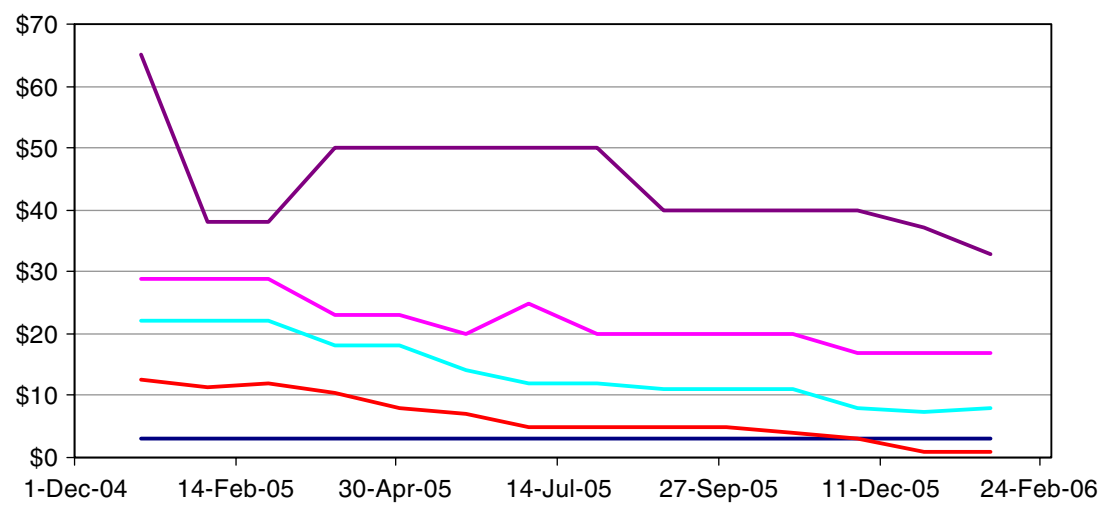




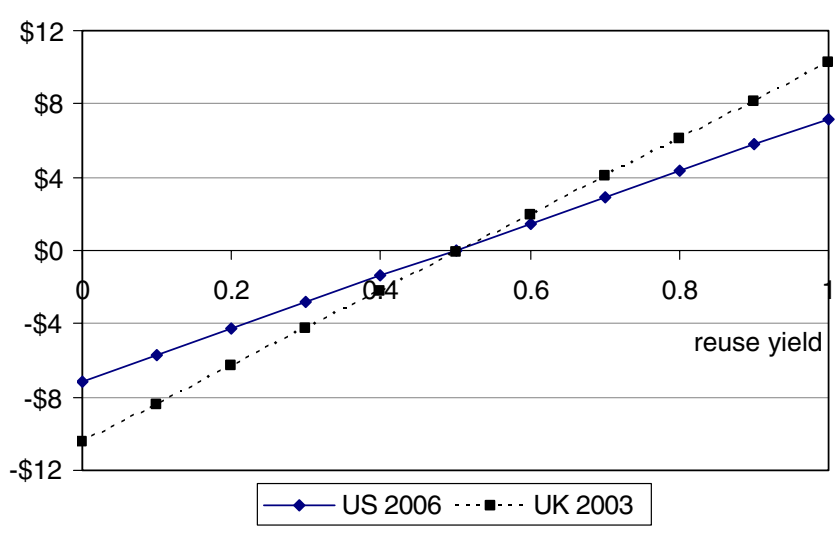

Fig. 5 Estimated operating profits of refurbishers in the USA in 2006 and the UK in 2003 as a function of the reuse yield $r$

recycling of cell phones. Not all cell phone manufacturers see refurbishment as a threat, though. Most US experts we interviewed believe that cannibalization rates are very low or even negligible. Combined with the assumption that firsttime buyers of reused cell phones are likely to upgrade to new handsets when the reused ones are retired, reuse could even be regarded as stimulating future sales of new products, while leaving current sales unaffected. In this case, handset reuse would turn from an economic threat into an economic opportunity for handset manufacturers.

Unfortunately, the largest environmental benefits of cell phone reuse and recycling lie precisely in their potential to displace the new production of handsets and precious metals. In a different paper, which assesses the environmental benefits of cell phone reuse and recycling, we argue that displacement rates for cell phone reuse and recycling are the single most important factor in the environmental performance of these closed-loop supply chains yet are currently unknown (Geyer R, Doctori Blass V. The role of displaced production for reuse and recycling: the example of cell phone end-of-life management. J Ind Ecol, under review). Most experts believe that displacement rates of secondary metals are likely to be very high, while those of cell phone reuse are likely to be very low. This could mean that the actual environmental benefits of cell phone reuse are lower than those of recycling, which would be a reversal of the conventional wisdom that reuse is environmentally preferable to recycling. To settle this issue, more research is necessary to establish robust estimates for the respective displacement rates.

\section{Conclusions}

This paper presents detailed economic data on cell phone collection, reuse, and recycling. The data clearly show that profitability of cell phone reuse is currently by far the largest driver of end-of-use handset collection, both in the USA and in Europe. In fact, the reverse logistics of cell phone recycling currently appears to be entirely financed by cell phone refurbishers and could thus be regarded as a byproduct of cell phone reuse. On its own, cell phone collection and recycling could never be done profitably, even if reverse logistics costs were to be minimized. Without reverse logistics costs, cell phone recycling currently has a small profit margin, which is substantially lower than it was 15 years ago. This profit margin could not be increased through the recovery of more materials than the currently recycled copper and precious metals, which already make up $95 \%$ of the metal value of cell phones, and also critically depends on the amount of gold in cell phones and its market value. Reuse, on the other hand, currently offers a solid profit margin. Refurbishers that collect handsets for reuse or recycling are profitable as long as their reuse yield is above $50 \%$. Since cell phone owners tend to keep their handsets beyond their use time and resale values of reused handsets decline quickly over time, the main challenge of take-back enterprises is to reduce the hibernation period of end-of-use handsets in the bottom drawer of their owners. More research should thus be conducted to assess how effective different reverse logistics strategies are in reducing the time between product end of use and return.

It is currently unclear to what extent cell phone reuse cannibalizes new product sales and thus reduces new handset production. The potential of reuse to cannibalize new cell phone sales is an economic threat to cell phone manufacturers, in particular since they are not engaged in reuse themselves. Cell phone refurbishers may thus also prefer low displacement rates in order to obtain the cooperation of the manufacturers. In the most optimistic case, refurbishers have no or little interest in the displacement dynamics of cell phone reuse, since their profitability is driven by the reuse yield, not by the displacement rate. Unfortunately, for many reuse and recycling activities, displaced production is what generates most of their environmental benefits. This means that the economic incentives of cell phone manufactures and refurbishers are currently not well aligned with the environmental performance of reuse.

Acknowledgements The authors thank Seth Heine (CollectiveGood), Thomas Hogye, Ken Taggert and Steve Ryan (ECS), Jason Else (Else Refining), Dr. Grant Kirkman (Greener Solutions), Craig Boswell (Hobi), Pam Arrigo (Motorola), Dr. Lucy Wright, Jake McLaren, Ed Butler and David Conrad (Nokia), Stephane Burban and Chuan-Hai Teh (Noranda), Mike Roselius (PaceButler), Gareth Rice (Panasonic), Mike Newman, Jennifer Chambers and Brandi Farwig (ReCellular), Bobby Aultman (RMS), and Sarah Bond (Shields) for their generous help with the research. Company affiliations are of the time of research and may no longer be up-to-date. 
Open Access This article is distributed under the terms of the Creative Commons Attribution Noncommercial License which permits any noncommercial use, distribution, and reproduction in any medium, provided the original author(s) and source are credited.

\section{References}

1. Nokia (2005a) Integrated product policy pilot project stage 1 report. Nokia, Espoo, Finland, January 2005

2. Mawston N (2008) Motorola, Sony Ericsson and Apple Lose Global Handset Marketshare in Q1 2008, Research Report, 25 April 2008, Strategy Analytics, Newton, MA

3. WEEE (2002) EU directive 2002/96/EC (WEEE directive). J Eur Union L37:24-38

4. CPRA (2004) Cell Phone Recycling Act (CPRA) of 2004, Assembly Bill 2901, State of California

5. Geyer R (2004) Environmental and economic evaluation of supply loops and their constraints, $\mathrm{PhD}$ Dissertation, Centre for Environmental Strategy, University of Surrey, UK

6. Doctori Blass V, Favret L, Fuji M, Mahdavi S, Miller R, Neira $\mathrm{J}$ (2006) End-of-life management of cell phones in the United States, Master's Thesis, Donald Bren School of Environmental Science and Management, University of California, Santa Barbara, CA

7. Clift R (1997) The ECTEL trials. J Ind Ecol 1(2):3-5

8. Wright L (1999) Product life cycle management, EngD Thesis, Centre for Environmental Strategy, University of Surrey, Guildford, UK

9. McLaren J, Wright L, Parkinson S, Jackson T (1999) A dynamic life-cycle energy model of mobile phone take-back and recycling. J Ind Ecol 2(1):77-91

10. Clift R, Wright L (2000) Relationship between environmental impacts and added value along the supply chain. Technol Forecast Soc Change 65:281-295

11. Stutz M, Franz R, Tzscheutschler P (2000) Energy use in the life cycle of a cellular phone: a study of the impacts during manufacturing and use. Proceedings of EGG 2000, 11-13 Sept 2000, Berlin, Germany

12. Oiva L, Oppermann W, Middendorf A, Zuber K-H, Stobbe I (2000) Case study on the environmental impacts of a mobile phone. Proceedings of EGG 2000, 11-13 Sept 2000, Berlin, Germany

13. Lindholm ME (2003) Toward environmentally conscious product design - a comprehensive DfE implementation in new generation cellular phones. Proceeding of the ISEE 2003, 19-22 May 2003, Boston, MA, USA

14. Takala R, Tanskanen P (2002) Outlining opportunities of engineering process and technology on environmental impacts of the end of life treatment of mobile terminals. Proceedings of IMAPS Nordic Annual Conference, September 2002, Stockholm, Sweden

15. Guide VDR (2000) Production planning and control for remanufacturing: industry practice and research needs. J Oper Manag $18: 467-483$

16. Guide VDR, Van Wassenhove LN (2002) Closed-loop supply chains. In: Ayres RU, Ayres LW (eds) A handbook of industrial ecology. Edward Elgar, Cheltenham

17. Guide VDR, Van Wassenhove LN (eds) (2003) Business aspects of closed-loop supply chains. Carnegie Mellon University Press, Pittsburgh

18. Basdere B, Seliger G (2003) Disassembly factories for electrical and electronic products to recover resources in product and material cycles. Environ Sci Technol 37(23):5354-5362
19. Seliger G, Skerlos SJ, Basdere B, Zettle M (2003) Design of a modular housing platform to accommodate remanufacturing of multiple cellular phone models. Proceedings of EcoDesign 2003, Tokyo, Japan, 8-11 Dec 2003

20. Guide VDR, Teunter RH, Van Wassenhove LN (2003) Matching demand and supply to maximize profits from remanufacturing. Manuf Serv Oper Manag 5(4):303-316

21. Skerlos SJ, Seliger G, Morrow WR, Chan K-Y, Basdere B, Zhao F, Hula A, Prasitnarit A (2003) Economic and environmental characteristics of global cellular telephone remanufacturing. Proceeding of the ISEE 2003, 19-22 May 2003, Boston, MA

22. Bhuie AK, Ogunseitan OA, Saphores J-DM Shapiro AA (2004) Environmental and economic trade-offs in consumer electronic products recycling: a case study of cell phones and computers. Proceeding of the ISEE 2004, 19-23 May 2004, Phoenix, AZ

23. McLaren J, Piukkula N (2004) Life cycle assessment of a $3 \mathrm{rd}$ generation Nokia handset. Proceedings of EGG 2004, 6-9 Sept 2004, Berlin, Germany

24. Malmodin J (2004) Summary of the study "life cycle assessment of a third generation (3G) system at Ericcson". Ericcson Radio Systems, Stockholm

25. Pesonen I (2002) Development of eco-efficiency of base stations by means of the MIPS indicator. Ministry of the Environment, Helsinki

26. Frey SD, Harrison DJ, Billet EH (2006) Ecological footprint analysis applied to mobile phones. J Ind Ecol 10(1-2):199-216

27. Huisman J (2004) QWERTY and eco-efficiency analysis on cellular phone treatment in Sweden, TU Delft, The Netherlands, commissioned by El-Kretsen, Stockholm, Sweden

28. Scharnhorst W, Althaus H-J, Classen M, Jolliete O, Hilty LM (2005) The end of life treatment of second generation mobile phone networks: strategies to reduce the environmental impacts. Environ Impact Asses Rev 25:540-566

29. HML (2004) E-waste report: determination of regulated elements in seven types of discarded consumer electronic products, Hazardous Material Laboratory (HML), Cal EPA

30. Townsend TG, Vann K, Mutha S, Pearson B, Jang Y-C, Musson S, Jordan A (2004) RCRA toxicity characterization of computer CPUs and other discarded electronic devices, Report to US EPA, University of Florida, FL

31. Lincoln JD, Ogunseitan OA, Shapiro AA, Saphores J-DM (2007) Leaching assessments of hazardous materials in cellular phones. Environ Sci Technol 41(7):2572-2578

32. Uryu T, Yoshinaga J, Yanagisawa Y (2003) Environmental fate of gallium arsenide semiconductor disposal. J Ind Ecol 7(2):103-112

33. Nokia (2005b) Integrated product policy pilot project stage 2 final report: options for improving life-cycle environmental performance of mobile phones, Nokia, Espoo, Finland, September 2005

34. Nokia (2006) Integrated product policy pilot project: stage 3 report: evaluation of options for improving life-cycle environmental performance of mobile phones, Nokia, Finland, April 2006

35. MPPI (2005) Environmentally sound management of end-of-life mobile phones. Mobile Phone Partnership Initiative. Basel Convention, UNEP, Geneva

36. ITU (2007) World telecommunication/ICT indicators database, 11 th edn. International Telecommunication Union, Geneva

37. Yuan L (2007) Upgrading a call on emerging markets. Wall Street J, 6 September 2007

38. DEFRA (2003) A study on mobile phones and the potential for recycling other small electrical and electronic products. Request for tender. Department for Environment, Food and Rural Affairs, London

39. Saphores J-DM, Nixon H, Ogunseitan OA, Shapiro AA (2006) Household willingness to recycle electronic waste: an application to California. Environ Behav 38(2):183-208 
40. Mayers K, France C, Cleverly A, Kabouris E, Planas S (2002) The use and disposal of IT products within commercial markets. J Bus Ind Mark 17(5):357-376

41. Coopers T, Mayers K (2000) Prospects for household appliances. E-SCOPE, London

42. SSMR (2001) Mobile phone user survey. Surrey Social and Market Research Ltd. (SSMR), Guildford

43. Mayers K (2001) An investigation of the implications and effectiveness of producer responsibility for the disposal of WEEE. EngD Thesis, Centre for Environmental Strategy, University of Surrey, Guildford, UK

44. Sullivan DE (2006) Recycled cell phones - a treasure trove of valuable metals. United States Geological Survey (USGS), Denver

45. EPA (2008) Fact sheet: recycle your cell phone-it's an easy call, EPA530-F-07-046, January 2008, US EPA

46. MPPI (2006) Guideline on material recovery and recycling of end-of-life mobile phones. Mobile Phone Partnership Initiative. Basel Convention, UNEP, Geneva

47. Scharnhorst (2006) Life cycle assessment of mobile phone networks, with focus on the end-of-life phase, $\mathrm{PhD}$ Thesis, École Polytechnique Fédérale de Lausanne, Switzerland

48. Teh C-H (2006) Personal communication with Chuan-Hai Teh. Noranda Recycling, San Jose
49. ECS (2006) Personal communication with Thomas Hogye, Ken Taggert and Steve Ryan. ECS Refining, Santa Clara

50. Shields (2002) Fonebak information package. Shields Environmental plc, South Ockendon

51. Stutz M, Burkhard C, Ertel J (2002) Cost elements of recycling and the design of mobile phones in the context of WEEE. Proceedings of Going Green CARE Innovation, 25-28 Nov 2002, Vienna, Austria

52. Hainault T, Smith DS, Cauchi DJ, Thompson TA, Fisher MM, Hetzel C (2000) Minnesota's multi-stakeholder approach to managing electronic products at end-of-life. Proceedings of ISEE 2000, 8-10 May 2000, San Francisco, CA

53. Else (2003) Internal documents. Else Refining \& Recycling Ltd., Shefford

54. USGS (2007) Minerals yearbook, 2007. United States Geological Survey (USGS), Denver

55. Kirkman GA (2003) Personal communication with Grant A Kirkman. Greener Solutions, London

56. Blackburn JD, Guide VDR, Souza GC, Van Wassenhove LN (2004) Reverse supply chain for commercial returns. Calif Manage Rev 46(2):6-22

57. Guide VDR, Muyldermans L, Van Wassenhove LN (2005) Hewlett-Packard Company unlocks the value potential for timesensitive returns. Interfaces 35(4):281-293 